\title{
The Binga outreach: A critical reflection on the reformed church in Zimbabwe's cross-cultural ministry
}

\section{Christopher Munikwa \& H Jurgens Hendriks ${ }^{1}$}

\begin{abstract}
This article describes the first cross-cultural outreach of the Reformed Church in Zambia (RCZ) to a non-Shona speaking group. This Church founded preaching posts and, eventually, a congregation among the Tonga people living in the Binga area on the southern side of the Zambezi River / Kariba Lake. These people, of a unique culture, were displaced from their land, causing great suffering, when the dam was built and the lake formed. They received very little compensation - if any. Other tribes looked down on the Tonga people. In the nineties, University students initiated an "evangelism outreach." This article describes the events, relates something about the Tonga people, and deals with the RCZ's discovery that they were defaulting to the missionary methods of the Dutch Reformed Church (DRC) that founded their Church more than a hundred years earlier. This realization led to the question how they should go about reaching out to different cultural groups of people.
\end{abstract}

Keywords: Cross-cultural; intercultural; mission; Tonga people; Binga; Reformed Church in Zimbabwe.

\section{Introduction}

The main purpose of this article is to contribute towards developing a communal and contextual missional framework that will encourage the Reformed Church in Zimbabwe's (RCZ) faith community's reflective involvement in the Mission of God. The problem addressed is the RCZ's struggle to develop appropriate mission approaches that will contribute meaningfully towards being a catalyst of cultural transformation. The RCZ, uncritically and conservatively, still cling to the traditional missionary model inherited from the European missionaries. This does not conform well to Zimbabwe's present and quite different socio-cultural circumstances. This study investigates the following hypothesis, formulated as a statement:

Christopher Munikwa is the current General Secretary of the RCZ. His email address is chrismunikwa@gmail.com . This article is based on Chapters 4 and 5 of his doctoral dissertation (2011:123-182). Jurgens Hendriks is a professor in Practical Theology and Missiology at Stellenbosch University and, together with Dr DX Simon, he was Munikwa's promoter. Hendriks' email address is hjh@sun.ac.za . 
A contextual and communal $^{2}$ approach in intercultural ${ }^{3}$ mission will transform all parties involved towards becoming a missional ${ }^{4}$ church.

This article assesses the RCZ's expression of mission while focusing on the Binga outreach. The RCZ's outreach in Binga started as a cross-cultural ministry. ${ }^{5}$ This work is unique in the RCZ, as it is an effort to proclaim the Gospel to a non-Shona ethnic group. It also is a recent development in the RCZ that focuses on a particular ethnic group in Zimbabwe who still live in relative isolation (Munikwa 2011:30).

The researcher's personal involvement in the RCZ outreach motivated this study. His interest sprang from the observation that this mission of the RCZ needed to be well equipped to address the present-day challenges and questions that the people were facing in their contexts. In the light of her mission, the $\mathrm{RCZ}$ must critically and constructively assess the theory and practice of mission

2 Ukpong (1999:112) points out that community is one of the fundamental characteristics of the African worldview. In the Zimbabwean context, a person's identity is communal and is expressed in relation to others. The communal perspective of life must be treasured and affirmed as the only basis on which constructive human relationships can be built in Christian faith (Kritzinger 2002:149,152,156). That which is communal is holistic or integral; it is collective and interdependent, not individualistic. In Africa, a strong awareness of interdependence exists, as opposed to the individualism of European culture. Moyo (1996:17) states that life can be meaningful only if it is life in communion with, and among, others.

3 An intercultural mission advocates the members to remain faithful and committed to participate without assuming any sense of superiority over others (Asamoah-Gyadu 2002:16). This is not understood to be cross-cultural ministry. Intercultural mission is deeply rooted in people's community and contextual realities, where there is active dialogue and reciprocity (Kgatla 2002:53). Kritzinger (2002:146) explains that this empowers one to become a sensitive intercultural Christian. In this research, "an intercultural encounter" means the mutual participatory process that shapes both the RCZ and the Tonga people through active communal dialogue (Munikwa 2011:30). This matter is discussed in more detail in an article by Munikwa \& Hendriks (2011:453-464).

"Missional" refers to being sent by God (Guder 1998:4). It denotes the purpose of God's action in human history that aims at transforming reality (Bosch 1991:390, Kritzinger \& Saayman 1994:4). Missional should not be equated with the traditional missionary model of sending missionaries to foreign countries. The concept is theocentric (Hendriks 2001:78). Craig Van Gelder (2007:17) explains that the focus of missional conversation is not to define the church around what it does (purpose), and how it does (strategies in context), but about what the church is, i.e. its nature. This research's premise is that the missional church is a faith community formed by God's calling and sending, communally and contextually reflecting his redemptive reign in Jesus Christ through the Holy Spirit (Munikwa 2011:27).

5 The argument is that cross-cultural understanding of ministry is a one-sided approach of the Gospel presentation from one culture to the other. Zwana (2007:75) refers to cross-cultural process as an invasion of one cultural context by another with a superior attitude. Saayman (1990:308) explains that "cross-cultural" implies too strongly that there are only two cultures involved in mission and also bears the implication that one of these cultures is Christian and superior. 
that the DRC missionaries transmitted to her. If she fails to evaluate and transform herself analytically in a holistic/integral and contextual way, she will be irrelevant and will not transform the lives of the Tonga people.

\section{The Dutch Reformed Church ${ }^{6}$ (DRC) and mission}

The DRC in the Netherlands planted the DRC in South Africa. A better understanding of the latter's mission is possible if related to, and placed in, various contexts of the European people's history (Saayman 2007:2, Munikwa 2011:34-65). This Church's missionary enterprise started during the colonial period. The paradigms of the Protestant Reformation and Enlightenment profoundly influenced the missionary understanding and practice of the DRC who was involved in cross-cultural ministry in many countries in Africa, including Zimbabwe. ${ }^{7}$

The DRC's Cape Synod of South Africa sent missionaries to Zimbabwe led by AA Louw. The missionary activities, which various Mission Committees managed and administered, were referred to as the Dutch Reformed Church Mission (DRCM) whom the researcher views as the missionary arm that followed the DRC's mission policies and practices (Munikwa 2011:80). The DRCM used what was technically known as a comprehensive approach as its method of mission, based on the premise that the proclamation of the Gospel had to be combined with education, medical, agricultural and industrial activities (Van der Merwe 1982:122, Kritzinger \& Saayman 1994:53). All the DRC missionaries were convinced of the correctness of their traditional missionary model (Kritzinger \& Saayman 1994:54, Saayman 2007:5).

The positive value of the DRC missionaries' work in Zimbabwe can hardly be denied. The researcher believes that the Zimbabwean people owe respect to, and appreciation of, the DRC because of her mission work. However, her work also had a negative side. Bosch (1991:237) reminds us that there can be no doubt that the old paradigm of doing mission certainly had its dark side, yet it also had its positive contributions. Saayman (2007:126) points out that the DRC mission, with all her frailties and failures, was a human vessel containing a heavenly treasure. Therefore, critical analysis needs to be carried out concerning the attitude and strategies of mission in the RCZ today.

The DRC missionaries used the mission-station approach. Bevans and Schroeder (2004:261) point out that this focused on individual conversions and a tendency to isolate people from their social context. In the researcher's view, the establishment of mission stations was destroying the

6 "Dutch Reformed Church" is a translation of Nederduitse Gereformeerde Kerk (NGK).

7 A whole chapter describes the DRC mission and the formation and development of the RCZ (Munikwa 2011:66-122). 
Zimbabwean communal understanding of life and forcing the culture of individualism (Munikwa 2011:83). Mashoko (2005:43) states that the idea of mission stations also separated the missionaries from the people of Zimbabwe it lacked identification with the indigenous people. The researcher contends that the missionaries did not take seriously, and were not sensitive to, the socio-cultural context of Zimbabwe's people. The problem with the DRC's traditional missionary model is the contextual and cultural factor.

The researcher believes that the cultural context of the local people is more important than the context of the person involved in mission. The RCZ members, as disciples of Jesus Christ involved in Christian mission, must acknowledge and recognise their own context's influence on their perception and practice.

\section{The identity of the RCZ in mission}

Upon a critical examination of the RCZ, one realizes that she reflects the missionary model inherited from the DRC missionaries. Lingenfelter $(1998: 12,172)$ explains that most churches in Africa reflect the culture of the missionaries who planted them. Moyo (1996:47) argues that, for the Gospel ${ }^{8}$ to become the Good News, it must be heard in, and through, the cultural context of the local people. Jesus expressed the love of God through the local Jewish cultural context in order to transform humanity and create newness and wholeness.

The article assumes, firstly, that the missionaries failed to do mission in such a way that the Gospel adequately penetrated the lives of the Karanga people who constitute the majority of the RCZ members. Their culture was only superficially ${ }^{9}$ transformed. Many RCZ Christians attend the Church regularly but, when faced with problems and challenges, they secretly resort to indigenous healers at night and many Zimbabwean Christians participate in private indigenous religious ceremonies. They live as European Christians during the day, but practise real African life at night. The Gospel of Jesus has not become flesh. Ekechi (1993:299) points out that, one way or another, the past and present Christians continue to seek solutions to their

8 The Gospel is the Good News of God's transformative love to the world in Jesus Christ. Moyo (1996:1) defines the Gospel as the message that calls people to faith in Jesus Christ. The aim of the Gospel is to transform people and their culture through the Holy Spirit.

9 The article understands "superficial life" as the outward appearance of accepting something. Many scholars, such as Desmond M. Tutu, John S. Pobee, David J. Bosch and Felix K. Ekechi, have pointed out that many Christians in Africa have dual lives. The European missionaries' failure to contextualise the Gospel message produced this dualism in African Christians. Berends (1993:276) states that, in the contemporary African medical system, dualism is evident in Christian mission. Many people make use of both European and African indigenous medicine. 
social and spiritual problems through indigenous African religious practices. Walls (2002:18) argues that they are unable to trust wholly as, according to their experience, nothing in the European model of the Church offers a defence against the worst features of their world. This made it difficult to address adequately problems such as the reality of spirits and demons, illness or any other problem associated with evil powers and magical forces (Bowen 1996:140). European missionaries failed to comprehend the reality of evil forces, witchcraft and other indigenous beliefs. An African views the world as populated with evil spirits. Ukpong (1999:111) argues that the Church should equip Christians for spiritual warfare against evil forces.

Mwaura (2004:105) explains that this misconception has created a vacuum in African people, which the African Initiated Churches (AICs) and Pentecostal Churches filled with their emphasis on the Holy Spirit's work that manifested in healing, exorcism, deliverance and prosperity. The AICs represent a serious attempt by Africans to introduce the Gospel into African culture by expressing it in images familiar to Zimbabwean indigenous people, thus responding concretely to their needs and aspirations (Moyo 1996:31). Some members of the RCZ, who believed that their needs were not adequately addressed, joined the growing African Initiated and Pentecostal Churches that originally were founded in Zimbabwe. In her ministry to the Tonga people, the RCZ has demonstrated an inability to deal with similar issues. The researcher argues that many RCZ members present a life of superficial Christianity, and he fears that this Church may reproduce superficial Christianity in the Tonga people's lives.

A second assumption is about ethnicity. The DRC's mission work concentrated on one ethnic group, thus creating an ethnic or tribal Church. This was, and still is, a problem as RCZ members in all the provinces are, basically, Karanga people. Viewed historically, the DRC missionaries in Zimbabwe were influenced by the South African situation. One of the DRC's characteristics was that of being an ethnocentric Church. If the RCZ continues to view and express herself as an ethnic Church, she will be unable to be involved faithfully in the Mission of God. The researcher believes that a missional church should be able to embrace all races and ethnic groupings. Today, the RCZ is known, sadly, as the Church of the Karanga people (Kereke yemaKaranga) as it has few members from other ethnicities, such as the Ndebele, Korekore, Manyika, or others in Zimbabwe. Therefore, in doing cross-cultural ministry, she has been unable to develop sufficient sensitivity to cultural differences.

The third assumption deals with worship. How one does Christian mission can be diagnosed in your worship. The foundation of the faith community's active reflective engagement with God's praxis is evident in the patterns of the Church's worship and practice (Hendriks 2001:81). In 
Africa, music and dance is an indispensable aspect of the Christian faith - it expresses the Christians' joy (Kritzinger 2002:169).

However, in the RCZ, the emphasis is upon uniformity that leads to rigidity. It is sad to note that flexibility is condemned because, it is argued, it distorts church traditions. Theological rigidity tends to limit the Church's effectiveness when responding to current daily challenges and realities. In reflecting on the HIV epidemic in Africa, Chitando (2007:1) calls upon African churches to be effective and flexible in their approach.

Inflexibility is dangerous. It kills and destroys the initiatives that the Holy Spirit raises in the faith community. The Church must dynamically embrace flexibility. Failure in this respect and insensitivity to the current contextual realities in Zimbabwe may lead to unnecessary conflicts in the RCZ. As reflected in Lukas Soko's (2010) research, schisms in the Reformed Church in Zambia indicate the dangers of inflexibility and insensitivity in the Church. The Holy Spirit does not enforce uniformity, but multiplicity in the ministry of the Gospel. The faith community is one body consisting of many members, whom the Spirit calls to special forms of ministry, endowing them with grace (Jay 1978:152).

Worship should be contextual; we must seek ways to worship God in an African way. Ukpong (1999:106) points out that African Christians question critically the mode of worship in the mainline Churches. This is also true of the situation in the RCZ. Why should RCZ members worship God while applying foreign styles of worship and symbols? The AICs have designed worship patterns compatible with an African sense of worship by implementing local drums, rattles, dancing and the clapping of hands (Ukpong 1999:106, Mashoko 2005:9).

The reality of our present context is that we live in a world of diversity and variety. The challenge is how to promote and facilitate growth as a faith community and inspire one another to participate reflectively in our proclamation of the Kingdom of God in Christ Jesus. In this modern world, the Church is to understand that no single form and style can express the Christian faith wholly on its own. Cray (2004:18) points out that the diversity of fresh expressions of a worshipping style is inevitable.

The other challenge that the RCZ faces is that she is still rooted in a model that was, and still is, monopolised by her ordained people (Dingemans 1996:84, Hendriks 2001:74). Bosch (1991:467) states that, in virtually all church traditions, ministry has been understood almost exclusively in terms of the service of the ordained ministers - the church has been clericalised (Rutoro 2007:11). All the members of the Body of Christ should, in a communal way, be given space and encouraged to participate actively in mission (Munikwa 2011:97). In the traditional missionary model, missionaries were sent to distant mission fields. 
Today, the critical question for the $\mathrm{RCZ}$ is whether an alternative framework for expressing the Gospel message is possible.

This question must be wrestled with in the Binga area - one of the contexts where the RCZ participates in the Mission of God. We must investigate how the initial $\mathrm{RCZ}$ outreach was done; the purpose being to help the RCZ to reach out in a sensitive intercultural way.

\section{The Tonga people}

In Zimbabwe, up to 16 languages or dialects are spoken, of which Chishona and Sindebele are dominant. In the Binga, Omay and Nyaminyami districts, Chitonga is one of the minority dialects (Tsiko 2004:7). As of 2009, the Tonga people are the third largest ethnic community in Zimbabwe. Some of the Tonga community are able to speak Chishona and Sindebele (http://en.wikipedia.org/wiki/ Tonga_people_of_Zambia_and_Zimbabwe. 2010/03/01). Zimbabwe has diverse cultures with no single African culture (Chitando 2007:2).

The Tonga people are in the north-western part of Zimbabwe bordering Zambia. They have lived along the Zambezi River for many years (Reynolds \& Cousins 1989:24, Colson 1971:3) and are mostly subsistence farmers, living below the poverty level. With their communal lifestyle, they constitute about $8 \%$ of the Zimbabwean population (http://www. mapsofworld.com/zimbabwe /culture/tonga.hmtl. 2010/03/3). The African way of life is described as ubuntu, but in Shona the term is hunhu. The essence of ubuntu/hunhu is being human, characterized by communality, interdependence and values such as compassion and hospitality, with a belief in harmonious existence and friendship. A Tonga proverb; Simwenda alike kakamulya kalonga, says: "The one who walks alone by the river gets eaten." They appreciate the importance of walking with another for companionship and the preservation of life.

People in our country mostly misunderstand, and look down upon, the Tonga community (Munikwa 2011:124). The researcher confesses that he also had misconceptions about the Tonga people while growing up and before the RCZ embarked upon the Binga outreach.

The situation in Zimbabwe, as well as that of the outside world, influences the Binga situation. Globalisation profoundly restructures the way people live (Giddens 2000:22). To a certain extent, it has had an impact even on the most remote rural communities, including the Tonga society (Hendriks 2004:15, Giddens 2000:22). The Tonga people were displaced in the 1950 s - the beginning of their great suffering. Without their consent, the colonial government resettled them for the purpose of a major technical development: the building of the Kariba dam (Tremmel 1994:42). Now, this development generates electricity and has accelerated tourism, but has dislodged the Tonga society (Munikwa 2011:127-128). 


\section{The Binga outreach}

The work was called "the Binga outreach," because its purpose was to evangelise the Tonga people who live along the Zambezi River in the Binga district.

At the University of Zimbabwe (UZ), the youth fellowship of the $\mathrm{RCZ}$ is involved in evangelising ministry. They visit the RCZ mission stations to share the Gospel with high school students. This fellowship wrote a letter to the then General Secretary of the RCZ, Rev Jude Zingoni, sharing their vision and desire to contribute towards an evangelism fund (Munikwa 2011:174). The Synod of 1994 accepted this idea and decided to form an Evangelism Committee (RCZ Synod minutes 1994:1047/40, 1050/88). This initiative did not originate at the top, but from below, the students. To go to Binga was a unique phenomenon, as this was a mission to a non-Shona group (Munikwa 2011:174).

In August 1995, during the Zimbabwe school holidays, the RCZ arranged her first outreach in Hurungwe among the Korekore people. The Hurungwe district is in the northern part of Zimbabwe, in the Mashonaland West province. Chikorekore is one of the Shona dialects. The researcher played a pivotal role in the discussions with the then General Secretary and he led the outreaches, as discussed in this article. At that time, he was a minister of the Chinhoyi congregation. Hurungwe was one of the areas that resorted in the Chinhoyi congregation (Munikwa 2011:175).

The outcome of this evangelising ministry was the planting of churches at Chikova and Chibara in Kazangarare, near the town of Karoi. In 1996, a church building and a house were built at Dete with the help of a DRC Karoi congregationalist, $\mathrm{Mr} \mathrm{P} \mathrm{Nel}$, a commercial farmer. After two years of catechism classes, the researcher was privileged to baptize and confirm 26 new members in the new church building.

From the outreach in Hurungwe, through her Evangelism Committee, the RCZ decided to reach out to the Tonga people. The Church budgeted for the outreach in Binga and some RCZ members contributed towards the Evangelism fund. From the experience of the Hurungwe outreach, the Evangelism Committee planned orientation training for all the prospective outreach team members. During the orientation period, the team members were taught the basic ways of communicating the Gospel. Many other relevant topics were also addressed to equip the team for this evangelising ministry. The team members were able to minister to groups as they moved from one homestead to the next, which proved to be effective.

The team consisted of volunteers from all the congregations in Zimbabwe, young and old, men and women. Since 1995, the average number of members in an outreach team has been 100. Currently, all the congregations contribute to the evangelism fund, but volunteers are not expected to contribute much. This has encouraged many volunteers to 
participate in the evangelising ministry. This encouragement was essential, as the RCZ moved to minister among the Tonga people.

In 1996, the outreach team went to the Binga district among the Tonga people. The team members were stationed at Tinde School near the Kamative mine in Binga. The team received some orientation on Gospel presentation and the Tonga culture. The orientation included discussions on the Tonga people's lifestyle. One of the Tonga explained their cultural systems to the team. This was done to help the outreach team members to appreciate the Tonga people's culture and to understand that their Shona culture was not superior to that of the Tonga. We had no RCZ written training literature for the team members, but simply experimented on methods of reaching out.

After the training, the outreach team walked from homestead to homestead. The group was divided into small teams of about ten people that included Tonga people who had joined as interpreters. The team members needed translators as the Tonga language is not of the same dialect as Chishona. The team comprised 64 members from 19 congregations, including five ministers, one minister's wife, one evangelist and one youth counsellor, and they called this process "hut-to-hut evangelism."

The outreach team shared the Gospel with 662 people, of whom 301 wanted to adopt the Christian faith. The team left the work to $\mathrm{Mr}$ Kangachepe Emmanuel Banda to disciple the people on spiritual growth. He later trained at Murray Theological College (MThC) as a lay-preacher. On cultural issues, the team taught the new believers to live according to biblical teachings. This meant that if any practice contradicted the Bible, such as witchcraft or alcoholism, one was to change. This outreach enabled the RCZ to establish two new posts. The leadership of Hwange congregation ${ }^{10}$ were to disciple the new faith community, which is recorded in the RCZ Evangelism Committee's report dated 9 October 1996. The cross-cultural ministry within the Tonga people then continued to grow.

In 1997, through her Evangelism Committee, the RCZ planned another outreach among the Tonga community. The people of Binga chose the Siachilaba School as the base for the outreach team, which proclaimed the Gospel of Jesus Christ for a week. The Gospel was presented to 1619 people of whom 395 accepted the Word. The team of 88 members were divided into eight groups (RCZ Evangelism Committee report 1997:1). This outreach resulted in the planting of two preaching posts at Binga Business Centre and Siachilaba. In 1998, the outreach team went to the Pashu area. The Gospel was shared with 1107 people of whom 292

10 Hwange is the nearest RCZ congregation and is about $100 \mathrm{~km}$ from Tinde School where the RCZ started her evangelising ministry among the Tonga people. 
accepted Christ. The 92 team members were divided into 10 groups (RCZ Evangelism Committee report 1998:9-11), which led to the establishment of preaching posts at Pashu and Manyanda.

In 1999, the large group of volunteers now included many RCZ Tonga members. So, the outreach group was divided into two teams, one at Sianzundu School and the other at Manjolo School. At Sianzundu, the 65 team members, divided into 10 groups, presented the Gospel to 1350 people of whom 306 accepted Christ. At Manjolo, the team of 70 members, divided into 12 groups, presented the Gospel to 1556 people of whom 318 accepted Christ (RCZ Evangelism Committee report 1999:1-2). During these four outreaches, preaching posts were established. However, in 2000, the outreach team were unable to travel because of a fuel crisis in Zimbabwe.

In 2008, the growth of the ministry among the Tonga people led to the establishment of a new congregation, named Binga RCZ, under the Bulawayo presbytery. The RCZ sent Rev R Manhongo to the new congregation as a missionary pastor. The RCZ Synod office supports him financially.

The reports of the outreach team reflect the positive work that the RCZ is doing in Binga and indicate that the members were trained to respect the Tonga people's culture. The critical question to which the Church must respond is: How should the RCZ help the Tonga people to address their social challenges and realities?

\section{Challenges of the Binga outreach}

The process of ministering to people of other cultures will always be fraught with challenges. The first being how the outreach team members relate to people of another culture. In general, people in Zimbabwe look down on the Tonga people. Mutual acceptance of human dignity and respect is at the very heart of any healthy human relationship. When approaching a person in any way - whether to help, teach, or learn from him/her - how that person is viewed is of crucial importance (Bruwer 1994:32).

The other challenges are socio-economic-political issues in the Tonga culture and life. Binga is one of the rich districts in terms of resources, yet the Tonga people's whole area is the least developed and poorest in Zimbabwe. Now, 30 years after liberation from the colonial government, not a single direct tarred road connects this district to Harare, the capital of the country; one must travel through Bulawayo. ${ }^{11}$

11 As the Binga business centre is very close to Harare, it is more expensive to travel through Bulawayo. The direct distance could be approximately $500 \mathrm{~km}$ whilst the route through Bulawayo is about $800 \mathrm{~km}$. It is sad to note that there is only one tarred road in the Binga district - that which the colonial government made. No tarred road connects the two districts where the Tonga people live (Nyaminyami and Binga). 
The issue of poverty is closely related to the issue of land and water. The Tonga people were displaced from fertile lands and an abundant water supply of the Zambezi River. The colonialist government promised them that they would enjoy a better life after the Kariba Dam had been built, but this never materialised. Now, they are bitter. Their land is rich in natural resources, such as wildlife, but outsiders reap the benefit. Electricity, to which they have no access, is generated on their doorstep and huge pylons that uphold the cables carry electricity to other parts of Zimbabwe over their heads.

The area of the Tonga community has the least medical and educational services in the country. An area of about $250 \mathrm{~km}$ has two hospitals and a few clinics that are very far from most people. Since the country received its independence, it is sad to note that the area has only two "A" level high schools, and A levels are required for access to the university. Furthermore, in this vast area there is not a single college. Educating a person is empowering the person.

The RCZ has addressed some of these challenges. In her attempt to empower the newly planted church, the RCZ identified the need to train leaders. Among the first converts, three Christians were trained: two women as youth counsellors (Esinath Moyo and Miriam Moyo), and one man as an evangelist (Reuben Ncube). The Church appointed Mr KE Banda as a lay-preacher to serve the Tonga people at Tinde and, a few years later, $\mathrm{Mr}$ Monga Enock Ndhlovu was also trained as an evangelist. The Committee's prayer and desire was that Tonga people should be trained as ministers. For effective community building, the people and their leaders must be empowered (Munikwa 2011:180).

The Evangelism Committee recognized the Chitonga-speaking people's need for literature. According to research, the Bible is the primary literature for any believer and should be in his/her language. Tonga Bibles are available but are difficult to obtain from Zambia. However, the RCZ has been challenged to ensure that the Tonga people have enough Bibles at their disposal. The Synodical Committee approved the Evangelism Committee's proposal that the RCZ hymn book and liturgy be translated into Chitonga. One of the evangelists, $\mathrm{Mr} \mathrm{ME}$ Ndlovu from Binga, received the responsibility to lead this process. Together with other Tonga-speaking members in Binga, Mr ME Ndlovu helped with the translation of literature.

The RCZ has not only preached the Gospel in word, but also in deed. The church, in partnership with the Gereformeerde Zending Bond, has built a clinic at Tinde near the Kamativi Mine. Upon the Tonga community's request, a church building and a house for the minister were also erected. The RCZ Synod office provided the plans (designs) of both buildings without any contributions of the Tonga members.

In an attempt to address the educational needs of the Tonga people, the RCZ established two primary schools, named Mabobolo and Manyanda. 
They are still under construction but were nevertheless opened so that pupils could start using them. The RCZ is also in the process of developing the community's own leadership.

This account of the Binga outreach has been done by making use of the RCZ Evangelism Committee's reports and the personal observations of the researcher who has been involved in the process. It proves that the RCZ has the vision and desire to participate in the Mission of God. The researcher believes that this is commendable. However, upon reflecting on the outreach, and in the process of studying the history and identity of the RCZ, the researcher was amazed to what extent he himself and the RCZ simply defaulted to the DRC's methods for mission (Munikwa 2011:66-122).

\section{Conclusion}

This article critically described the work of the RCZ among the Tonga people. It discussed the Binga outreach as an extended case study. On this journey, the problem that surfaced is that the RCZ is failing to develop appropriate meaningful and relevant approaches to being a catalyst of transformation. A realistic fear exists that the problems that the RCZ experiences with its own members by reverting back to traditional religious practices and witchcraft, are not addressed in the Binga outreach.

The goal is to determine how the RCZ can move towards a communal-contextual missional framework and avoid the mistakes that the DRC made in working cross-culturally, instead of inter-culturally. On the positive side one notes the following:

The research proved that the Binga outreach is a unique phenomenon in the RCZ as it is a ministry among a non-Shona group. The argument is that the RCZ, as a Church of Jesus Christ, should reject the planting and development of separate racial or ethnic churches (Saayman 2007:14). The inclusion of Christians from a different language group should provide the $\mathrm{RCZ}$ with a better understanding of the universality of the Church of Christ, as the Korekore, Tonga, and Ndebele people become a part of this Church.

The story of the UZ (University of Zimbabwe) students has shown the importance of providing space for people of all ages in the Church to participate in God's mission. The students were able to share their vision and desire to contribute towards an evangelism fund. Therefore, the RCZ needs to redouble her ministry among college and university students. With good, effective leadership they will help the Church to cross traditional boundaries.

In retrospect, one is thankful that training of the Evangelism Teams indeed took place and that cultural issues were addressed, albeit with little theoretical knowledge on mission methodology! The fact that Tonga people were asked to explain their cultural practices and that leadership recruitment 
from the Tonga people themselves took place from the very beginning should be regarded in a very positive light.

However, the following are concerns:

The RCZ should not simply translate its own liturgy, songs and hymns into Chitonga. The Church should allow the new Tonga members to develop a liturgy that is relevant and appropriate to their cultural context. It should be a liturgy that allows them to express themselves as Tonga people, not as Shona people. This illustrates that the RCZ applies the model that the DRC missionaries used in planting churches in Zimbabwe.

The Tonga people must be involved in their own evangelisation. The researcher agrees with Hedlund (1991:274) who says that mission is not the monopoly of any one person, group, or structure; but is the obligation of every church and believer. The Tonga people were involved in the outreaches, but how and in what capacity should be reconsidered.

The new Tonga Church should have been allowed the opportunity to participate in preparing the plans of their church and the other building. The RCZ does everything for the Tonga people just like the DRC missionaries were doing.

The other issues relate to the development of the new Tonga Church structure. How does the new Church, planted as a result of the Binga outreach, relate to the RCZ? The RCZ should grant the Tonga Church space to develop. The RCZ must allow the outreach to the Tonga people to grow in line with their cultural context. In the process of developing the community's own leadership, the RCZ should be careful not to create a paternalistic relationship between its Synod and the Tonga people. The researcher acknowledges an evident tension between the two proposed principles. On one hand, the article outlines that the RCZ should avoid planting separate ethnic churches. On the other hand, give the Tonga people space to grow and develop in line with their cultural context, such as liturgy, leadership, etc. The researcher believes that, through the Holy Spirit, such tensions will be solved by means of critical communal dialogue between the $\mathrm{RCZ}$ and the Tonga believers.

The research has proved that the RCZ is still defaulting to the DRC's missionary model. Therefore, the RCZ should revisit her thinking about, and doing of, mission. She is to develop a communal-contextual-missional framework. Our present identity is challenged to be renewed in a process of profound listening to both the Word and the world. We are challenged to cross boundaries and reach out to "the other" - as "others" reached out to us long ago. In a context that has changed dramatically, the Bible and the Holy Spirit must guide us on this journey. The Gospel is relevant to all ages, times, cultures and peoples, but its ministry must be communally contextualised in order for it to be experienced as the living Word of God. 
We need to discuss intercultural mission as we journey together. In Africa, people realise that the Christian faith was communicated to us in European patterns and forms related to their socio-cultural perspectives (Ukpong 1999:101). In Africa, the question we have to ask continually is: How should the Gospel message be interpreted from the perspective of our daily contextual realities?

\section{References}

Asamoah-Gyadu, K 2002. Pentecostalism in Africa and the changing face of Christian mission: Pentecostal/charismatic renewal movements. Mission Studies, Vol XIX, 2-38, 14-39.

Berends, W 1993.African traditional healing practices and the Christian community. Missiology: An International Review., Vol XXI:3, 275-287.

Bevans, SB \& Schroeder, RP 2004. Constants in context: A theology of mission for today. Orbis Books, Maryknoll, New York.

Bosch, DJ 1991.Transforming mission: Paradigm shifts in theology of mission. Orbis Books, Maryknoll, New York.

Bowen, R 1996. So I send you. SPCK, London.

Bruwer, E 1994. Beggars can be choosers: In search of a better way out of poverty and dependence. Institute for Missiological and Ecumenical Research (IMER), University of Pretoria.

Chitando, E 2007. Acting in hope: African churches and HIV/AIDS. WCC Publications, Geneva.

Colson, E 1971. The social consequences of resettlement: The impact of the Kariba resettlement upon the Gwembe Tonga. Kariba Studies, Vol 4, Manchester University Press.

Cray, G 2004. Mission-shaped church: Church planting and fresh expression of church in a changing context. Church House Publishing, London.

Dingemans, GDJ 1996. Practical theology in the academy: A contemporary overview. Journal of Religion, Vol 78:1, 82-96, University of Chicago.

Ekechi, FK 1993. The medical factor in Christian conversion in Africa: Observations from south-eastern Nigeria. Missiology: an International Review, Vol XXI: 3, 289-309.

Giddens, A (1999) 2000. Runaway world: How globalisation is reshaping our lives. Routledge, New York. 
Guder, DL 1998. Missional church: A vision for the sending church in North America. Eerdmans, Grand Rapids.

Hedlund, RE 1991. The mission of the church in the world: A biblical theology. Baker Book House, Grand Rapids.

Hendriks, HJ 2001. Doing missional theology in Africa. In Hendriks, HJ, Luidens, DA, Nemeth, RJ, Smidt, CE \& Stoffels, H (Eds). Reformed encounters with modernity: Perspectives from three continents. The International Society for the Reformed Communities, Stellenbosch.

Hendriks, HJ 2004. Studying congregations in Africa. NetACT, Lux Verbi, Wellington.

Jay, EG (1977) 1978. The church: Its changing image through twenty centuries. SPCK, London.

Kgatla, ST 2002. Willem Saayman: A true African Afrikaner missiologist. Missionalia, Vol 30:1, 46-55.

Kritzinger, JJ \& Saayman, WA 1994. On being witnesses. Orion Publishers, Johannesburg.

Kritzinger, JNJ 2002. A question of mission: A mission of questions. Missionalia. Vol 30:1, 144-173.

Lingenfelter, SG 1998. Transforming culture: A challenge for Christian mission. Baker Books, Grand Rapids, Michigan.

Mashoko, F 2005. The need for contextualisation in intercultural communication of the Gospel. MTh thesis in missiology, University of South Africa.

Moyo, A 1996. Zimbabwe: The risk of incarnation. WCC Publications, Geneva.

Munikwa, C 2011. The Binga outreach: The contextualisation of mission in the Reformed Church in Zimbabwe. D.Th dissertation, Stellenbosch University. Available at: http://etd.sun.ac.za/handle/10019/5854

Munikwa, C, \& Hendriks, H.J., 2011, 'The Binga outreach: Towards intercultural mission in the Reformed Church in Zimbabwe', Dutch Reformed Theological Journal 52(3), 453-464. http://ngtt.journals.ac.za/pub/article/view/55

Mwaura, P 2004. African Independent Churches: The role and contribution of African Christianity. In: Bediako et al., 2004. A new day 
dawning: African Christians living the Gospel: Essays in honour of JJ Hans Visser. Uitgeverij, Boekencentrum, Zoetermeer.

RCZ, 1994. Synod minutes, 1047/40 and 1047/88. Masvingo, Zimbabwe.

RCZ, 1996. Evangelism Committee report, 1996. Masvingo, Zimbabwe.

RCZ, 1997. Evangelism Committee report, 1997, p 1. Masvingo, Zimbabwe.

RCZ, 1998. Evangelism Committee report, 1998, pp 9-11. Masvingo, Zimbabwe.

RCZ, 1999. Evangelism Committee report, 1999, pp 1-2. Masvingo, Zimbabwe.

Reynolds, P \& Cousins, 1989. Lwaano lwanyika: Tonga book of the earth. Baobab Books. Harare.

Rutoro, R 2007. Lay leadership development in the Reformed Church in Zimbabwe. D.Th dissertation, Stellenboch University. Available at: http://hdl.handle.net/10019.1/5490

Saayman, W 2007. Being missionary - being human: An overview of the Dutch Reformed Church. Cluster Publications, Pietermaritzburg.

Saayman, W 1990. Intercultural evangelisation. Missionalia, Vol 18:3, 308-319.

Soko, L 2010. A practical theological assessment of the schisms in the Reformed Church in Zambia (1996-2001). D.Th dissertation, Stellenboch University. Available at: http://hdl.handle.net/10019.1/5454

Tremmel, M 1994. The people of the great river. Mambo Press, Gweru.

Tsiko, S 2004. Herald. 17 May 2004, page 7.

Ukpong, JS 1999. Towards a holistic approach to inculturation theology. Mission Studies, Vol XIV: 2, 32,103-123.

Van der Merwe, WJ 1982. The witness of the church in Zimbabwe. Lovedale Press, Lovedale.

Van Gelder, C 2007 (ed). The missional church in context: Helping congregations develop contextual ministry. Eerdmans, Grand Rapids.

Walls, AF 2002. The cross-cultural process in Christian history. Orbis Books, Maryknoll, New York. 
Zwana, S 2007. Church-related universities as a manifestation of new frontiers in mission: The Zimbabwean experience. Missionalia, Vol $35: 2,71-88$.

\section{Websites}

http://www.mapsofworld.com/zimbabwe /culture/tonga.hmtl. 2010/03/3.

http://en.wikipedia.org/wiki/Tonga_people_of_Zambia_and__ Zimbabwe.

2010/03/01 